\title{
Vernáculo - 15 anos
}

Alysson de Avila Costa ${ }^{1}$

Há alguns meses fomos convidados, eu e alguns colegas da graduação, por dois amigos da pós, Hilton e Leonardo, para integrar a equipe da revista. O projeto apresentado era ambicioso: chamar artigos, conseguir material e periodizar as edições da revista, que se encontravam um pouco defasadas. Aceitamos prontamente o desafio, eu, Fran, Larissa, Monah, Fred e Bruna.

Para cumpri-lo, entretanto, tivemos que lidar com questões acadêmicas, burocráticas e pessoais. Ainda na graduação, nem sempre é fácil conciliar o calendário acadêmico, provas, trabalhos, monografia, com atividades extracurriculares. A revista, particularmente, demanda um bom nível de dedicação, preparação, elaborações, leituras, revisões, de tempo, enfim. Os bastidores da revista em si já demandam um tempo para aprender a lidar com seu ambiente e suas ferramentas, o fluxo das informações e o lugar de cada uma. E há ainda a proposta do trabalho ser desenvolvido colaborativamente, o que rende um aprendizado de vida constante.

\footnotetext{
${ }^{1}$ Graduado em História, UFPR, pesquisador do CEDOPE-UFPR
} 
É salutar elencar certas dificuldades, pois elas valorizam as nossas conquistas. O número 35 marca os 15 anos da revista - agora periodizada, com material para ser trabalhado para os próximos números, com um alto nível de colaboração de amigos, editores, pareceristas, e, principalmente, amigos interessados em mandar suas pesquisas e seus materiais para a Vernáculo.

Participar da revista por esses meses, já há pouco mais de um ano, foi gratificante. Nada disso teria sido possível sem o esforço e ajuda de muita gente, que não vou nominar, pois ou deixaria alguém de fora, ou usaria todo o espaço que tenho para transmitir essa mensagem. Mas registro aqui o meu agradecimento a quem nos ajudou a organizar números, a quem submeteu seus textos, a quem os avaliou e revisou; aos meus amigos da revista, da graduação e da pós, no Brasil ou fora dele, que de um jeito ou de outro, mesmo com pequenas ações, somaram para construção de tudo que a revista conquistou. 